\title{
Bacterial adhesion and disease activity in Helicobacter associated chronic gastritis
}

\author{
S J Hessey, J Spencer, J I Wyatt, G Sobala, B J Rathbone, A T R Axon, M F Dixon
}

\begin{abstract}
Ultrastructural examination of biopsies showing Helicobacter pylori associated chronic gastritis reveals close attachment between gastric surface epithelial cells and the organism. The finding of 'adhesion pedestals', which represents a cellular response to the presence of the organism, is analogous to the response of intestinal cells to enteropathogenic $E$ coli. Thus the development of bacterial attachment sites in $H$ pylori associated gastritis might be an indication of pathogenicity. We have therefore explored the relationship between the proportion of organisms forming attachment sites and histological indices of disease 'activity'. Antral biopsies from 40 patients with $H$ pylori positive gastritis were examined histologically and ultrastructurally, and the percentage of attached organisms compared with subjective assessments of epithelial degeneration, mucin depletion, polymorphonuclear and chronic inflammatory cell infiltration. We found a significant increase in the proportion of attached bacteria in cases showing histological epithelial degeneration, and a significant decrease in cases showing intraepithelial polymorph infiltration. The direct relationship between bacterial attachment and cellular degeneration lends further support to a pathogenic effect. Reduced attachment in the face of polymorph infiltration might indirectly reflect aspects of the immune response namely, blocking of adhesion by IgA, with complement activation and generation of leucotactic factors.
\end{abstract}

Since the identification and isolation of spiral organisms from the human stomach by Warren and Marshall ${ }^{1}$ in 1983, there have been numerous reports linking such organisms, now termed Helicobacter pylori, with active chronic gastritis. ${ }^{2-4}$ Despite immunological, ${ }^{5}$ ultrastructural,,$^{6-9}$ ingestion ${ }^{11} 11$ and treatment $^{12}$ studies, the pathogenicity of $H$ pylori remains controversial.

Previous ultrastructural studies have made reference to the close association between $H$ pylori and the gastric epithelium in chronic gastritis, ${ }^{69}$ and these epithelial attachment sites have been compared with those formed by enteropathogenic $E$ coli. ${ }^{6}$ The ability of $E$ coli to adhere to epithelial cells through a specialised attachment site, the 'adhesion pedestal' is important in the initiation of intestinal disease, ${ }^{13}$ and it could be that $H$ pylori gives rise to chronic gastritis in a similar manner. If this is so, then the

^The new nomenclature for Campylobacter pylori is Helicobacter pylori. (Leading article Lancet 1989, ii: 1019). development of specialised attachment sites represents an important aspect of pathogenicity and their presence and frequency should be related to the degree of gastritis.

The aim of this study was to investigate the morphological features of $H$ pylori adhesion at the ultrastructural level and to explore the relationship between bacterial attachment and the severity of gastric disease.

\section{PATIENTS}

Three adjacent antral biopsies were collected from each of 83 consenting patients complaining of dyspepsia, using an Olympus GIF Q10 endoscope. Two biopsies were fixed in formalin, paraffin embedded, and $5 \mu \mathrm{m}$ sections stained with haematoxylin-eosin (HE), Alcian Blue/ periodic acid-Schiff (AB/PAS) and the modified Giemsa technique. ${ }^{14}$ The latter was used to determine $H$ pylori positivity. The severity of chronic gastritis in each case was assessed by one pathologist (MFD) using the $\mathrm{H}$ and $\mathrm{E}$ and $\mathrm{AB} /$ PAS stained sections. In addition to assessing infiltration of the lamina propria (interstitium) and epithelium by polymorphs, which is the conventional criterion for defining 'active' chronic gastritis, attention was also directed towards mononuclear cell infiltration of the mucosa, mucin depletion and epithelial degeneration. Each of these five features was graded $0-3(0=$ absence, $1=$ mild, etc $)$ to reflect current disease 'activity' in a broader sense. Glandular atrophy and intestinal metaplasia were not assessed as these are considered to be indicators of duration and progress of the gastritis rather than activity.

The remaining biopsy from each patient was fixed for three hours in 3\% glutaraldehyde in phosphate buffered saline (PBS), $\mathrm{pH} 7 \cdot 4$, and then stored in PBS until the $H$ pylori status was known. In $H$ pylori positive cases, the tissue was orientated and routinely processed for transmission electron microscopy. $0 \cdot 1 \mu \mathrm{m}$ sections were stained with uranyl acetate and lead citrate and viewed independently (by SJH) using a Phillips 420T or a Joel 1200 Ex Electron Microscope.

Ultrastructurally $H$ pylori were seen either randomly scattered in the mucus layer or more frequently in close proximity to the plasma membrane of the surface or foveolar epithelial cells. $H$ pylori adhesion sites were defined as 'a close attachment between bacteria and epithelial cells such that no space is visible between them'. Adherent organisms were quantified in each case as a percentage of the total organisms present. The proportion of adherent organisms was related to the grades of severity of each of the five 
histological parameters as assessed in the adjacent formalin fixed biopsies. Statistical analysis was performed using the Spearman rank correlation and Mann-Whitney $U$ test.

A limited number of additional antral biopsies were stained with Ruthenium-red to show surface glycoproteins using a pre-embedding staining technique based on those of $\mathrm{Luft}^{15}$ and of Fowler. ${ }^{16}$ Three such biopsies came from $H$ pylori positive patients and were subjected to ultrastructural examination.

\section{Results}

Of the 83 dyspeptic patients, 45 had $H$ pylori associated gastritis of which 40 sets of biopsies proved to be suitable for concurrent histological and ultrastructural examination.

\section{ULTRASTRUCTURE}

$H$ pylori were seen to be darkly staining flagellated organisms with a double unit membrane. The outer wall was most densely stained and bore an extraneous layer of irregular, radially arranged fine fibrils. These were often condensed between the organism and epithelial cell producing an intervening 'fuzzy layer'. It was thought that these fibrillar structures might be pili but this was not confirmed by negative staining of cultured organisms with methylamine tungstate acid. Ruthenium red stained the epithelial cell brush border and the extraneous coat of the bacteria forming a granular deposit (Fig 1), this suggests the involvement of a negatively charged acidic polysaccharide in connecting the bacterial glycocalyx with that of the epithelial cell.

Where $H$ pylori were closely associated with epithelial cells, there was loss of microvilli with flattening of the plasma membrane which often had a degenerate appearance with outpouchings and blebs. The epithelium also showed depletion of mucin granules and some cytoplasmic loss, the

Figure 1: Transmission electron micrograph of ruthenium red stained $\mathrm{H}$ pylori adherent to the plasma membrane of surface epithelial cell. The granular deposits represent granular deposits represent
staining of glycosubstances covering the bacterium and associated with the cell glycocalyx.

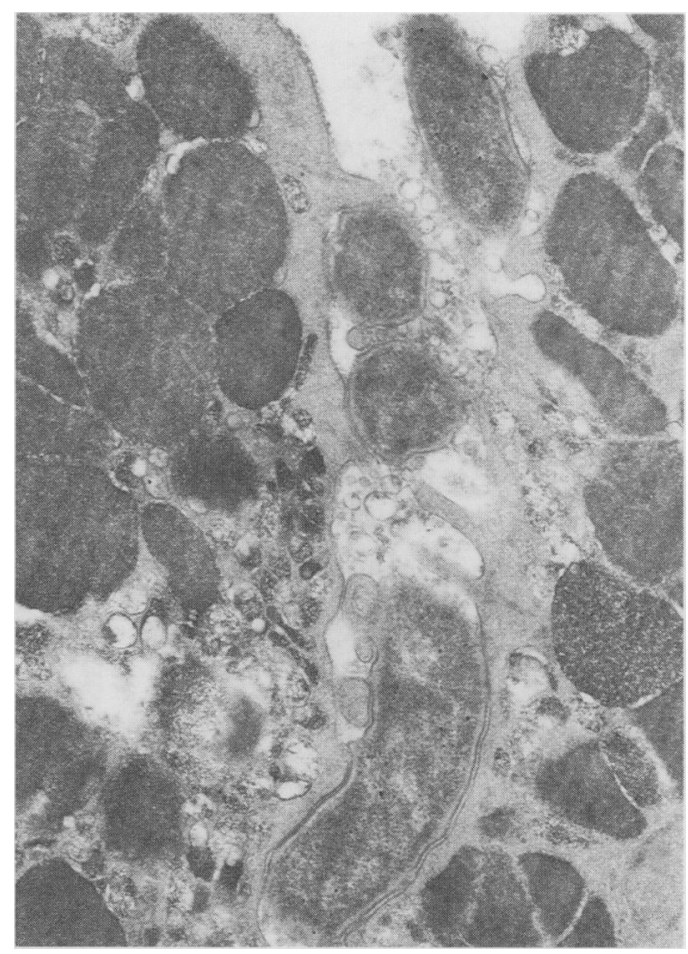

Figure 2: Transmission electron micrograph of antral amucosa showing organisms lodged in a cell junction. The adjacent cytoplasm of the epithelial cells shows vesiculation and accumulation of lysozymes.

cells becoming more cuboidal with an increased nucleo-cytoplasmic ratio. Where organisms had migrated between cells or were concregated in niches at pit bases, intracellular oedema, vacuolation and lysosome accumulation were observed (Fig 2). The latter changes, however, were not seen in surface cells exhibiting bacterial attachment on their luminal aspects alone.

Between 23 and 629 (mean=125.5, SEM= 24.8) $H$ pylori were found per biopsy. The wide variations in the number of organisms present in the ultrathin sections meant that comparisons based on absolute numbers of adhesion sites would be meaningless, accordingly adhesion has been expressed as a percentage of the total count of $H$ pylori found in each case. Between 0 and $41.5 \%$ (median $21.5 \%$ ) of the total bacteria formed adhesion sites. On the basis of the morphological appearances, three categories of adhesion site were observed: the adhesion pedestal where the epithelial cell forms a plateau like extrusion and cups the organism to varying degrees, as described for $E$ coli adhesion by Inman et $\mathbf{l}^{17}$ (Fig 3a); indentation sites where the organisms dip into the epithelial surface (Fig $3 \mathrm{~b}$ ); and abutting adhesion where apart from loss of microvilli, the contour of the epithelial cell is unchanged at the point of contact with the organism (Fig 3c). The majority $(67 \%)$ of adherent $H$ pylori were abutting; indentations and pedestals were less frequently seen $(17 \%$ and $16 \%$ respectively).

ULTRASTRUCTURE V DISEASE ACTIVITY In comparing the proportion of adherent organisms with histological disease activity, the three morphological categories of adhesion site have been grouped together because the significance of the different forms of adhesion is 


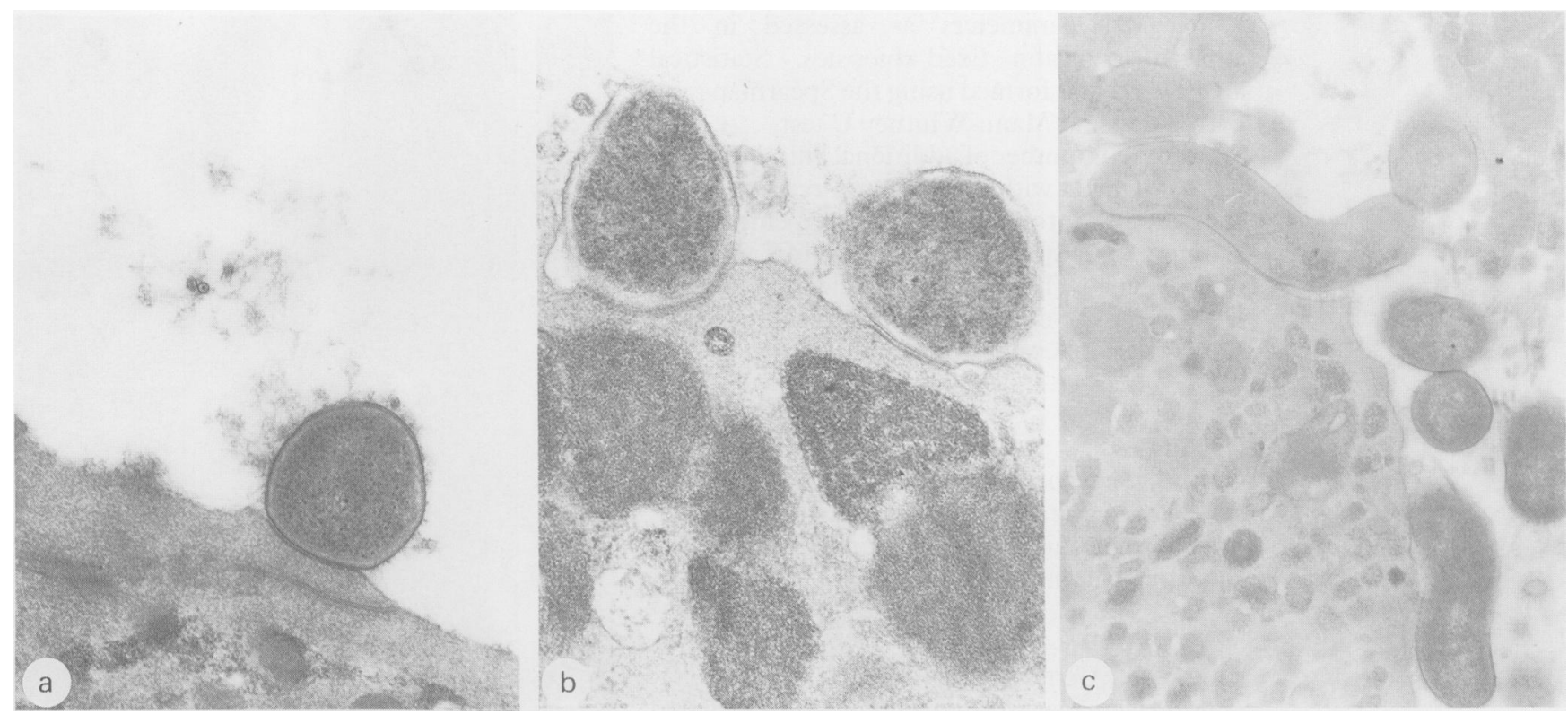

Figure 3a: Adhesion site with raised plasma membrane forming a plateau like extrusion - an adhesion pedestal; $(b) \mathrm{H}$ pylori occupying depressions in the plasma membrane constituting 'indentation' sites; (c) Organisms abutting onto the plasma membrane which is devoid of microvilli.

as yet unknown and it seems likely that they are all steps in a single adhesion process. The proportion of adherent organisms for varying degrees of severity of the five histological parameters are shown in the Table.

When the individual results for percentage adhesion were compared with the corresponding grades for the histological features using the Spearman rank correlation test, no significant relationship emerged. In a two category situation, however, significantly increased percentages of adhesion were found in cases showing epithelial degeneration (grades 1,2 and 3) when compared with those cases without degeneration ( $\mathrm{p}=0 \cdot 013$; Mann-Whitney U test). Epithelial degeneration (Fig 4) was always present when more than $20 \%$ of organisms were found to be adherent (Fig 5). In contrast, there was a significant decrease in the percentages of adherent organisms when intraepithelial polymorphs were seen (grades 1, 2 and 3 ) compared with the percentages found in the absence of polymorphs $(p=0.041)$.

Although increased adhesion was found with more severe mucin depletion, this did not reach statistical significance. Only one case showed absence of interstitial polymorphs but there was no difference in adhesion between mild (grade 1 ) and more severe grades ( 2 and 3 ) of interstitial infiltration. All cases showed some increase in chronic inflammatory cells over those found in

TABLE Mean percentage of adhesive $\mathrm{H}$ pylori found with increasing severity (grade) of five histological features

\begin{tabular}{llllll}
\hline Grade & $\begin{array}{l}\text { Epith } \\
\text { degeneration }\end{array}$ & $\begin{array}{l}\text { Mucin } \\
\text { depletion }\end{array}$ & $\begin{array}{l}\text { Interst } \\
\text { polymorphs }\end{array}$ & $\begin{array}{l}\text { Intra-ep } \\
\text { polymorphs }\end{array}$ & $\begin{array}{l}\text { Chronic } \\
\text { inflamm }\end{array}$ \\
\hline $\begin{array}{l}\text { Absent } \\
\text { or normal }\end{array}$ & $10 \cdot 2 \%[8]^{\prime}$ & $16 \cdot 6 \%[6]$ & $16 \cdot 4 \%[1]$ & $24 \cdot 4 \%[12]$ & {$[0]$} \\
\hline $\begin{array}{l}\text { Mild } \\
(2 \cdot 70)^{2}\end{array}$ & $(5 \cdot 51)$ & $(-)$ & $(3 \cdot 09)$ & $(-)$ \\
\hline $\begin{array}{l}2 / 3 \\
(4 \cdot 17)\end{array}$ & $\begin{array}{l}16 \cdot 6 \%[14] \\
(3 \cdot 48)\end{array}$ & $\begin{array}{l}19 \cdot 3 \%[29] \\
(2 \cdot 39)\end{array}$ & $\begin{array}{l}16 \cdot 2 \%[20] \\
(3 \cdot 02)\end{array}$ & $\begin{array}{l}20 \cdot 7 \%[16] \\
(3 \cdot 20)\end{array}$ \\
\hline $\begin{array}{l}\text { Moderate } \\
\text { /severe }\end{array}$ & $21 \cdot 2 \%[18]$ & $22 \cdot 6[18]$ & $19 \cdot 6 \%[10]$ & $19 \cdot 4 \%[8]$ & $18 \cdot 3 \%[24]$ \\
\hline
\end{tabular}

Figures in square parenthesis represent the number of patients in each category' (total $=40$ ), and the standard error of the mean. normal mucosa; the percentages of adhesion found in cases with moderate and severe infiltration were not significantly different from mild cases.

\section{Discussion}

When comparing the epithelial attachment of $H$ pylori to that of $E$ coli several features in common were noted, for example the loss of microvilli and membrane flattening, the loss of cytoplasm from involved cells and the ragged irregular luminal borders of such cells. The loss of the terminal web and depletion of glycocalyx which is typical of $E$ coli attachment to small intestinal cells ${ }^{18}$ was, however, not seen with $H$ pylori, but these structures are much less developed in gastric epithelial cells. The consistent finding of a 'fuzzy' layer, which proved to be Ruthenium red positive, indicates a role for glycosubstances in adhesion. Recent work has shown that oligosaccharide residues are

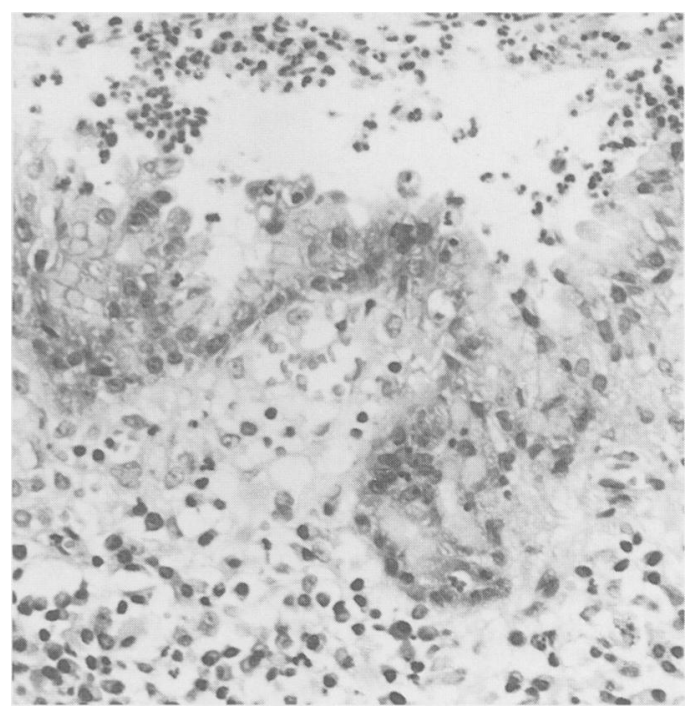

Figure 4: Antral biopsy on histology showing severe epithelial degeneration with irregular 'budding' of cells, heaping up of nuclei, and mucin depletion. These changes were found adjacent to a focal erosion. 


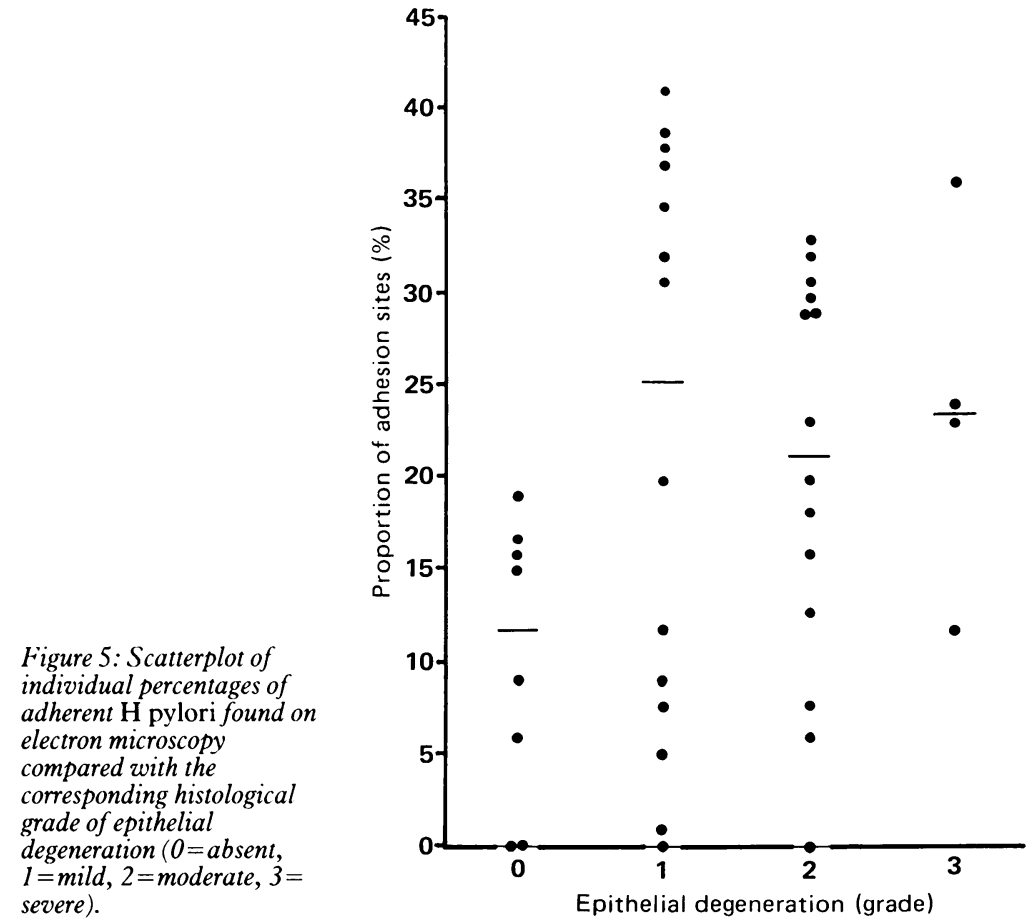

involved in ligand-bacterial interactions for $E$ coli, ${ }^{19}$ and after the completion of our study Evans et $a l^{20}$ have shown that $H$ pylori possesses a fibrillar $\quad \mathrm{N}$-acetylneuraminyllactose-binding haemagglutinin which the authors suggest is the adhesin responsible for epithelial attachment. Interestingly their results with immunogold staining show that the fibrillar antigen covers the entire bacterial surface in the form of a capsule like network, a picture analagous to that we obtained with Ruthenium red staining.

Previous ultrastructural studies on $H$ pylori associated gastritis have noted intracellular changes $^{821}$ similar to those in $E$ coli induced enteritis, 2022 including oedema, vacuolation, swelling of endoplasmic reticulum and lysosome accumulation. These more severe intracellular degenerative changes were not conspicuous in this study except where organisms had migrated between cells or were congregated in niches at
Figure 6: $\mathrm{H}$ pylori adherent to the 'roof' of a large intacellular vacuole lined by plasma membrane with well preserved microvilli and containing dense or finely granular material. the bases of the gastric pits. It seems likely that toxins released by the bacteria are responsible for the cell damage and exert a maximal effect when concentrated in areas such as the intercellular spaces. That $H$ pylori produces cytotoxins has now been established ${ }^{23}$ and Leunk et $a l^{24}$ have shown cytoplasmic vacuolation in a cultured intestinal cell line exposed to broth culture filtrates of the organism.

A feature not described in $E$ coli adhesion was the finding of intracellular cystic spaces which were partially filled with granular and amorphous material and lined by microvilli bearing a glycocalyx (Fig 6). These were observed in a minority of epithelial cells in three of the 40 $H$ pylori positive cases. They have been previously observed in Helicobacter-bearing epithelium by Fiocca et $a l,{ }^{21}$ and could be larger versions of the cytotoxin-induced vacuoles described by Leunk et al. ${ }^{2+}$ Similar intracellular 'cysts' are seen in some gastric carcinoma cells. ${ }^{25}$ The aetiology and significance of such cysts has not been elucidated, but presumably they represent atypical endocytic vacuoles.

Although 'activity' in chronic gastritis is conventionally defined by the presence and number of neutrophil polymorphs, for the purposes of this study we have broadened the term to include other possible responses to infection - that is, mononuclear cell infiltration, mucin depletion and epithelial degeneration. Degeneration was recognised histologically by ragged cytoplasmic margins, a high nucleocytoplasmic ratio, and heaping up of cells to form syncytia-like masses (Fig 4). While these cells invariably show loss of microvilli, distortion of the plasma membrane and loss of mucin granules on electron-microscopy, it is surprising that histological 'degeneration' was not generally paralleled by intracellular degenerative changes on electron-microscopy. Despite this, we found a significantly increased proportion of $H$ pylori exhibiting adhesion to the gastric epithelium in the presence of histological degeneration assessed independently by a second observer. In particular, epithelial degeneration was always present when more than $20 \%$ of organisms had formed adhesion sites. There are two possible explanations for this, either there is preferential attachment of $H$ pylori to previously damaged cells, or $H$ pylori adhesion plays a role in the production of cell damage. The first explanation seems unlikely; $H$ pylori do not colonise gastric mucosa injured by reflux gastritis ${ }^{26}$ or lymphocytic gastritis. ${ }^{27}$ On the other hand adhesion sites could produce damage, for example, by providing a site for direct toxin delivery from $H$ pylori to the epithelial cell, ${ }^{24}$ or by allowing localised luminal accumulation of harmful substances produced by the 'anchored' organisms. Whether $H$ pylori adhere before or after epithelial degeneration occurs could only be discovered by sequential studies in a suitable model system where the development of colonisation could be followed.

Mucin depletion was readily recognised in the AB/PAS stained sections and was a consistent feature of active gastritis. Loss of mucin granules was confirmed on electron microscopy. While more severe grades of mucin depletion were 
associated with higher proportions of adherent organisms, the differences failed to achieve statistical significance.

With regard to inflammatory cells, there were no significant changes in the percentages of adhesion with increasing infiltration by chronic inflammatory cells and polymorphs in the lamina propria. For intraepithelial polymorphs, however, there was a significant decrease in the percentages of adherent organisms in cases showing epithelial infiltration. This apparently paradoxical finding might be a consequence of the local immune response. Coating of organisms by IgA would inhibit adhesion and at the same time opsonisation by complement activated through the alternate pathway ${ }^{28}$ would both promote phagocytosis and generate complement products chemotactic for polymorphs. In this way, one could arrive at the inverse relationship between bacterial attachment and intraepithelial polymorph infiltration which we observed.

To conclude, we believe that the demonstration of a direct relationship between bacterial attachment and epithelial degeneration lends further support to the pathogenic role of $H$ pylori in the development of chronic gastritis.

1 Warren JR, Marshall BJ. Unidentified curved bacilli on gastric epithelium in active chronic gastritis. Lancet 1983; i: 1273-5.

Drumm B, Sherman P, Cutz E, Karmali M. Association of campylobacter pylori on the gastric mucosa with antral
gastritis in children. New Engl f Med 1987; 316: 1557-61.

3 Marshall BJ, McGechie DB, Rogers PA, Glancy RJ. Pyloric campylobacter infection and gastroduodenal disease. Med $\mathcal{F}$ Aust 1985; 142: 439-44.

4 Steer HW. The gastroduodenal epithelium in peptic ulceration. F Pathol $1985 ; 146 ; 355-62$.

5 Wyatt JI, Rathbone BJ, Heatley RV. Local immune response to gastric campylobacter in non-ulcer dyspepsia. Scand $\mathscr{f}$ Gastroenterol 1988; 23 (Suppl 142): 44-9.

6 Goodwin CS, Armstrong JA, Marshall BJ. Campylobacter pyloridis, gastritis, and peptic ulceration. F Clin Pathol 1986; 39: 353-65.

7 Chen XG, Correa P, Offerhaus J, et al. Ultrastructure of the gastric mucosa harboring campylobacter-like organisms. Am f Clin Pathol 1986; 86: 575-82.

8 Tricottet V, Bruneval P, Vire O, Camilleri JP. Campylobacter-like organisms and surface epithelia Campylobacter-like organisms and surface epithelial
abnormalities in active, chronic gastritis in humans: an abnormalities in active, chronic gastritis in humans:

9 Bode G, Malfertheiner P, Ditshuneit H. Pathogenetic implications of ultrastructural findings in campylobacter pylori related gastroduodenal disease. Scand 7 Gastroenterol 1988; 23 (Suppl 142): 25-39.

10 Marshall BJ, Armstrong JA, McGechie DB, Glancy RJ Attempt to fulfil Koch's postulates for pyloric campy lobacter. Med $\mathcal{F}$ A ust 1985; 42: 436-9.

11 Morris A, Nicolson G. Ingestion of campylobacter pyloridis causes gastritis and raised fasting gastric $\mathrm{pH}$. Am $\mathcal{F}$ Gastroenterol 1987; 82: 192-9.

12 Rauws EAJ, Langenberg W, Houthoff $\mathrm{HJ}$, Zanen $\mathrm{HC}$, Tytgat GNJ. Campylobacter pyloridis-associated chronic active antral gastritis: a prospective study of its prevalence and the effects of antibacterial and antiulcer treatment. Gastroenterology 1988; 94: 33-40.

13 Clausen CR, Christie DL. Chronic diarrhoea in infants caused by adherent enteropathogenic escherichia coli. 7 Paediat 1982; 100: 358-61.

14 Gray SF, Wyatt JI, Rathbone BJ. Simplified techniques for identifying campulobacter pyloridis letter. $\mathcal{f}$ Clin Pathol 1986; 39: 1279-80.

15 Luft JH. Ruthenium Red and Violet I; chemistry, purification, methods of use for EM and mechanism of action. Anat Rec $1971 ; 171: 347-68$

16 Fowler BA. Ruthenium red staining of rat glomerulus, perfusion of ruthenium red into normal and nephrotic ra kidney. Histochemistry 1970; 22: 135-62.

17 Inman LR, Cantey JR. Specific adherence of Escherichia coli (strain RDEC-1) to membranous $(M)$ cells of the Peyer's patch in Eschericia coli diarrhoea in the rabbit. $\mathcal{F}$ Clin Invest 1983; $71: 1-8$

18 Rothbaum R, McAdams AJ, Giannella R, Partin JC. A clinicopathologic study of enterocyte adherent Escherichia coli: a cause of protracted diarrhoea in infants. Gastroentrology 1982; 83: 441-54.

19 Rosenstein IJ Stoll MS, Mizuochi T, Childs RA, Hounsell EF, Feizi T. New type of adhesive specificity revealed by oligosaccharide probes in Escherichia coli from patients with urinary tract infection. Lancet 1988; ii: 1327-30.

20 Evans DG, Evans DJ, Moulds JJ, Graham DY. Nacetylneuraminyllactose-binding fibrillar hemagglutinin of Campylobacter pylori: a putative colonization factor antigen. Infect Immun 1988; 56: 2896-906.

21 Fiocca R, Villari L, Turpini F, Tu:pini R, Sokia E. High incidence of campylobacter-like organisms in endoscopic bioposies from patients with gastritis, with or without peptic ulcer. Digestion 1987; 38: $234+4$.

22 Cantey JR, Blake RK. Diarrhoea due to Esherichia coli in the rabbit: a novel mechanism. F Infect Dis 1977; 135: 45+-62.

23 Figura N, Guglielmetti P, Rossolini A, et al. Cytotoxin production by Campylobacter pylori strains isolated from production by Campylobacter pylori strains isolated from patients with peptic ulcers and from patients wit

24 Leunk RD, Johnson PT, David BC, Kraft WG, Morgan DR. Cytotoxic activity in broth-culture filtrates of campylobacter pylori. 7 Med Microbiol 1988; 26: $93-9$.

25 Nevalainen TJ, Jarvi $O H$. Intracellular cysts in gastric carcinoma. Acta Pathol Microbiol Scand [A] 1976; 84: 517 22.

26 O'Connor HJ, Dixon MF, Wyat JI, et al. Effect of duodenal ulcer surgery and enterogastric reflux on campylobacter pyloridis. Lancet 1986; ii: 1178-81.

27 Dixon MF, Wyat JI, Burke DA, Rathbone BJ. Lymphocytic gastritis - relationship to campylobacter pylori infection 7 Pathol 1988; 154: 125-32.

28 Dao SS, Karin QN Easmon CSF. Opsonophagocytosis of Campylobacter pylori. $\mathcal{F}$ Med Microbiol 1988; 27: 125-30. 